\title{
Corporate Legal Responsibility: A Levinasian Perspective
}

\author{
Conceição Soares
}

\begin{abstract}
In this article I will look into Corporate Legal Responsibility taking into account Levinas's notion of infinite responsibility, as well as his understanding of ethical language. My account of Levinas's philosophy will show that it challenges - breaking down - deeply entrenched distinctions in the dominant strands of moral philosophy, within which the theory of individual responsibility is embedded, such as between:(1) duty to others on the one hand and supererogation on the other; (2) perfect duty to others on the one hand and imperfect duties to others on the other; (3) insiders and outsiders; kith and kin on the one hand and strangers on the other; Levinas's moral vision is an inclusive one which embraces all of humanity (at least of those present today) irrespective of historical, linguistic, cultural differences and diversities. In other words, each has responsibilities for and duties towards all others. Of course, one might say that there is nothing new about a universalising ethics - after all Kantianism, liberalism as well as utilitarianism are well known instances. However, more crucially, all these traditional moral philosophies uphold the theory of individual responsibility, which is rooted in the philosophy of individualism. Such a philosophy can make sense only of the concept of individual moral/legal agency but not corporate agency. Therefore, in this article I will attempt to show that the Levinasian vision is able to help us change our view with respect to corporate responsibility.
\end{abstract}

KEY WORDS: corporate responsibility, justice, saying, Levinas, sociality, face

\section{Introduction}

If the spirit of the Levinasian account of infinite responsibility for the Other were to filter through to individual and social consciousness, then, perhaps, the powerful cultural resistance to corporate responsibility/culpability would be eroded. ${ }^{1}$ Society and its legal system (such as that in England and
Wales), as well as its moral outlook would be more ready to accept that corporations could be found guilty of even manslaughter, and be duly punished for it (as in the case of the Herald of Free Enterprise and similar tragedies $)^{2}$, or that they could be said to be morally responsible for the deaths/harm caused.

Levinas has also argued against the view - a denial that morality is grounded solely on autonomy, freedom and reason, and that moral obligation rests essentially on reciprocity. His two-pronged strategy affirmation on the one hand and denial on the other - opened the way for his central notion of infinite responsibility for the Other which in turn can be defended against the charge of either unintelligibility or absurdity. It is the reason I will raise a few more Levinasian concepts, which are particularly germane to the respective discussions of corporate legal responsibility.

\section{Justice and sociality}

Levinas agrees with Heidegger that philosophy is more than a method, rather that it is "a way of becoming aware of where we are in the world (Kearney (1984): 49)". Nevertheless, he held that the whole of Western tradition of philosophy, including Heidegger, has gone astray, because for Levinas ethics appears as first philosophy, and not only ontology or the study of Being - "Morality is not a branch of philosophy, but first philosophy (Levinas, 1967)." Levinas does not prescribe an ethic, his philosophy is far from being normative; nevertheless, by his descriptions and analyses, the ethical perspective is the starting point of his philosophy. The awakening for ethics happens, when the agent becomes aware of a responsibility, which is beyond his/her control, of a desire for the Other. 
Furthermore, infinity, is really another name for responsibility for the Other.

This latter point is brought out by Levinas's emphasis on ethics as first philosophy, rejecting the dominant view of individual responsibility which is based on a sense of the self, as a spontaneous (autonomous/free/rational) being; ${ }^{3}$ instead he sees the self (myself) as a being in relation to an other, who ex hypothesi is not myself (that is, the same), but whose strangeness and whose irreducibility to the I (my memories, my thoughts, my feelings as well as my material possessions) calls precisely into question my spontaneity and autonomy for free action.

The face (le visage) is irreducible, being primordial; it encapsulates the Other, as well as its strangeness and the awareness of otherness on my part.

The face is a living presence; it is expression. The life of expression consists in undoing the form in which the existent, exposed as a theme, is thereby dissimulated. The face speaks. (TI: 66).

The face of the other calls me to justice ${ }^{4}$ and to justification. On it is written, as it were, the commands: "Thou shalt not kill", "Thou shalt love thy neighbour as thyself", "Thou shalt do all that thou canst to help the other", in spite of the defencelessness and powerlessness of the Other. The face, however, should not be understood merely in terms of physical characteristics. But it remains true that physiognomy crucially renders communication possible between the other and myself.

The basic structure of language is a relationship between two singularities, "I", and the "Other". In speaking, the Other is solicited, called upon to respond. In speech, the I and Other solicit each other without appropriation. That is, in speech ${ }^{5}$ or communication there is the true encounter with the Other.

Encounter with the Other which occurs in faceto-face dealings with other human beings also points beyond itself towards absolute otherness, recognition of which is recognition of genuine transcendence, beyond Being, or Otherwise than Being. ${ }^{6}$ This absolute other or infinity cannot be comprehended in the way traditional metaphysics has tried to do; it is revealed not in intellectual comprehension but in actual discourse - "Better than comprehension, discourse relates with what remains essentially transcendent (TI: 195)". Discourse preserves the "I" in its individuality, as well as the distinctiveness of the other, the distinction between the same and the Other.

Ethics for Levinas, is not based on reciprocity (I acknowledge the demands of others only in return that they acknowledge my demands upon them), or on the Golden Rule - to do unto others what you would like others to do unto you; nor is it a question of advancing enlightened self-interests. Our obligations to others do not arise through entering into contracts with them to protect our mutual interests or our separate rights. The "mercantile" calculation of a utilitarian kind, or the rational manoeuvrings of a Kantian kind, the Nietzschean will to power, or the Sartrean pursuit of infinite freedom is alien to the Levinasian orientation. All these perspectives are profoundly individualistic in orientation, which begin with, and end at the egocentric starting point, and therefore the self simply acts to defend itself from the other while at the same time assaulting the freedom of others in order to aggrandise itself.

Levinas distinguishes between sociality (and true society), on the one hand, and society, on the other, a distinction, which enables him to look at the social order in a way different from the usual one. ${ }^{7}$ Society, commonly understood in modern social philosophy, amounts to the following:

1. It is a multiplicity of human beings.

2. Particular human beings are individual instances of the genus "human being" who are equal autonomous subjects with equal rights.

3. The main problem in social philosophy is the question of how a multitude of such autonomous and equal individuals can form a more or less harmonious and peaceful society.

4. Such individuals undertake actual or potential roles, functions without, however, any attempt to grasp and place these in their different contexts of social formations.

Sociality, thus defined by Levinas as the (always) possible encounter with the Other in his/her strangeness, is therefore distinct from society as commonly understood. In Levinas, the social relation is not reduced to culture, race or a common affiliation to land. Neither does he subscribe to the various philosophies of the social contract in which freedom is the basis of the social relation, or to those philosophies in which autonomy of the will is the 
basis. He does not reduce the human being to a mere "member of society (Levinas, 1998)". His account of the social relation has its source in the sentiment of the disquieting strangeness of the Other.

For a culture steeped in individualism and its related key concepts of instrumentality, rationality and autonomy, such a call of infinite responsibility for others is at once challenging and disturbing.

\section{Corporate legal responsibility: the Saying and Said}

In the context of corporate legal responsibility, it seems to me that the most relevant of Levinas's notions is the distinction between what he calls the Saying and the Said. ${ }^{8}$ So I must give a brief account of it.

For Levinas the priority of ethics is based upon the primordiality of language. The pursuit of justice which is intrinsic to morality is tied up with language, and is to be understood through the distinction between the Saying and the Said.

In the context of the discussion here, one can argue that the Said contains everything that comes under a Code in the legal sense of the term, and the Saying is the speech that inspires the spirit of the law. In the context of a corporation and, according to French's terminology ${ }^{9}$, the Said is the Corporation's Internal Decisions Structure (CID) and the Saying is the speech that inspires the CID. But the Saying is always in excess of the Said as it is the condition of the possibility of discourse; however, there is always the threat of betrayal of the Saying by the Said. This is the reason why Levinas warns us that the social relation which supposes justice could be a more vulnerable relation than the face-to-face relation, or in other words, to forget the Saying is only to pretend to close the others in a collective frame, to reduce the human plurality to a multiplicity. At the level of corporations this reduction implies that the logic of the economic system - geared to capital accumulation and profits always with exponential growth and accountability to shareholders as its targets - in which corporations operate, would not readily go hand in hand with the Levinasian requirements of responsibility for the Other. But the precise virtue of approaching the matter from a Levinasian perspective is that the latter forces one to address the deficiencies of the theory of individual responsibility in the context of liberalism and of the market. Levinasian insights can help us to articulate the relevance of responsibility on the part of corporations to others beyond share-holders. One can say that a corporation's social interactions with others fall, at least, into four categories:

1. Interchanges between individual agents.

2. Corporations interacting with individual agents.

3. Corporations interacting with other corporations.

4. Corporations interacting with society.

Corporations in their relations and actions, as is obvious and already mentioned, have far more power and control over many others than individual agents because they, by and large, structurally constitute the situations in which individual agents have to operate and make choices. For instance, in a recent article in The Guardian, John Pilger (2001) wrote about the inhuman conditions and low wages in which people are forced to work and live, to be able to survive under the dictum of globalisation, where big companies, such as Gap or Nike exercise their power, depriving the workers of a free and dignified life.

However, the problem, as shown by the example of the Herald of Free Enterprise, is that corporations in the majority of the cases are typically insensitive to such matters and ignore them.

In Otherwise than Being, Levinas presents the notion of justice as one with a double structure justice as a question, and justice as a problem. From the asymmetrical point of view, the Other always has primacy, (après vous, monsieur or "after you, Sir"). One starts the analysis with the question: who goes in the first place? Who has primacy? In the case of corporations and taking into account what I have said previously about the four social interactions with others, the answer to this question is even more complex than in the case of individual agents. However, as an example, one can ask: is it more important to respond to the interests of the share-holders and the pressures of competition or to respond to the matter of the safety of passengers by improving the safety of the equipment with which the corporation runs its business? This 
question is a question of justice. The responsibility for the Other presupposes asymmetry, non-reciprocity and disproportion.

The state which gives the possibility for justice is not for Levinas the arbiter of power based on relations of force; it is not the state of the Leviathan. And to judge is not to subsume the particular case under a rule. The same can be said in relation to a corporation, whose particular interests should not be subjugated to corporate goals. In the specific case of the Herald of Free Enterprise, the good service to customers could not be neglected (especially in matters relating to safety) in the name of particular interests, namely the challenges of competition or the pressure of shareholders to increased profits. A corporation should be organised according to the principle of justice, which means, following Levinas, that if the responsibility for the Other "is the surplus of my duties over my rights", then the order of justice is one in which duties override rights. ${ }^{10} \mathrm{~A}$ corporation is just in its relations when its social interactions are based on the inequality of the ethical relation; injustice begins when one loses sight of the alterity of the Other and forgets that the corporation is informed by my relation to the Other. Or as Levinas says, "this means that nothing is outside of the control of the responsibility of the one for the other (OB: 159)." - concern for the law, concern for justice, concern for the responsibility for the Other.

For Levinas, responsibility is given in the asymmetrical relation between the I and Other. In saying this, he is not denying the need for law, which is not meant to relieve the agent of his/her responsibility for the Other, but to ensure that this responsibility does not transform itself to become injustice. This means that interpersonal responsibility is extended to all the others; the domain of the collective becomes visible in the face-to-face relation. The aim of the law is to do justice to all the others, without at the same time neglecting the asymmetrical relationship of the face-to-face.

We are not only responsible for the intended consequences but also for the unintended consequences of our actions, because the core of the Levinasian notion of responsibility is an infinite responsibility in the first person. $M e$, voici (here I am); not only for the Other, but also for all the absent others who look at me in the eyes of the Other. ${ }^{11}$ Equality is the foundation of justice, but Levinasian justice is not distributive justice, based on equality as proportion, but based on an asymmetrical disproportion. ${ }^{12}$ It follows from what I have said before about the CID in a corporation that a corporation chart is important. However, this chart is not valuable in itself and needs continuous questioning by the Saying, which means that in the complex net of interdependent and dependent relationships, a particular Other cannot be privileged to the detriment of another, but that the relations should be based on justice. The law sets upon the Said, from which it is possible to judge. However, this Said, codified, thematically treated, intrinsically requires for completion the Saying, but this Saying is not an origin, it is pre-originary, and non-synchronised with the Said. It is in this paradoxical relation between the two plans, indifferent to each other and yet at the same time linked, that Levinas sees justice as a problem. ${ }^{13}$ Against the peril of the degradation of justice, Levinas argues:

In no way is justice a degradation of obsession, a degeneration of the for-the-other, a diminution, a limitation of anarchic responsibility, a neutralization of the glory of the Infinite, a degeneration that would be produced in the measure that for the empirical reasons the initial duo would become a trio. (OB: 159)

The peril of this degeneration could come not from equality but from equality reduced to uniformity, as equality, which is the basis of justice, does not forget the inequality of responsibility.

Justice in Levinas is against conatus or force, which has neither boundaries nor limits. According to Levinas the legal system in its formalism is inspired by this inequality. However, this inequality and this excess are not the origin of law, since the law presupposes synchrony between a principle and its consequence, between the general and the particular. Justice is and must be the domain of the visible, nevertheless, Levinas permanently calls our attention to the fact that before the law, there is the preoriginal, an-archaic responsibility for the others. This reasoning when applied to a corporation means that the corporation has responsibility for each party which has a relationship to it, such as its customers, and that such responsibility should not be defected by or undermined in the name of rules, pressures, economic growth or profits.

The central question in this discussion is the fact that justice is not viewed as a formal or abstract 
legality regulating society, with the mere aim of producing social agreements by reducing conflicts. A society regulated by abstract legality is without faces and friendship; in other words, it is a society without a true recognition of human diversity and difference, in which economic abstraction and reification are represented by so-called free and equal autonomous individual. ${ }^{14}$ In Levinasian, terms this is a society without proximity. ${ }^{15}$

But responsibility as proximity, doubtless, exerts an enormous demand on me as a moral agent. It leaves me with two stark options: either I answer the call of the Other and through it discover the real meaning of myself, or I completely turn my back on such responsibility, thereby losing my true identity. Identity in Levinas is not acquired by free choices, but in the encounter with the Other as, "If I do not answer for myself, who will answer? But if I only answer for myself - will I still be myself'? ${ }^{16}$ The same reasoning can be applied to corporations, which cannot be indifferent to the fate of the people with whom they have relations, as its identity is ultimately linked with the way that they are able to respond to the different and multiple calls of the Others as customers, share-holders, society, etc. Furthermore, "the tie with the Other is knotted only in responsibility".

Like the individual moral agent, it is through responsibility that the corporation is able to discover its true aim and meaning. Its identity is given in the One for the Other, in the way it responds to the call of others with whom it has relations. ${ }^{17}$ Such a perspective implies that ethics is an inherent part of economic and corporate life. It is not simply a consequence of actions good, bad or indifferent performed by the individuals who form part of this life, but also that such life is part of ethical life itself, which is all embracing and all pervasive from which no domain of human activities can be insulated. In order to be human is to be responsible in this demanding Levinasian sense. In repudiating or shunning it, executive business suits must necessarily lead dehumanised lives, pretending that the ethical has no remit within their professional existence.

It is within institutions/corporations that we are placed in relation with other individuals, but the link which is established in the framework of an institution/corporation is organised "around something (Levinas, 1982)," and as I have mentioned above, a corporation is organised around a CID structure, aims and projects. The contact between individuals is not direct but through a common interest, an idea, or a project, which sustains it. Therefore, one can say that each individual belongs to a determinable and objective context given the function or role that he/she occupies in a particular social structure, as I have mentioned in the case of the Herald of Free Enterprise.

Levinas, in his analysis of society, takes into consideration the work of Durkheim and identifies in it an "elaboration of the fundamental categories of the social ... starting from the main idea that the social cannot be reduced to the sum of individual psychologies (Levinas, 1990)". The individual is not an abstract de-contextualised being; he/she becomes a moral agent from the instant that he/she places his/her centre of behaviour outside him/ herself and in this way his/her conduct indicates their necessary commitment to the Other and all others. Levinas appreciates the way that Durkheim considered the spiritual/moral dimension of the individual in its organicist dimension, in the sense that the society is a whole, constituted by distinct but interdependent parts. Levinas recognises in Durkheim a "metaphysician" of the social, because Durkheim is capable of demonstrating that society is structured as a totality, which presupposes that a social totality has its own reality, apart from that of the individuals that constitute it. The social totality defines the organisational systems of a social group, be these economic or legal. In the "social of Durkheim" Levinas recognises the value of the social totality, as a structured whole. For Levinas, the interest of Durkheim lies in the fact that for the latter, the coexistence of individuals within a social totality is not simply a bald fact, but that social totality makes possible the elevation of the individuals to morality. This presupposes that the individual and society are not separate and independent of each other, but that human action can only be understood within the complex nexus of relations and interrelations in a determined context.

By analogy, this kind of Levinasian/Durkheimian reasoning would enable one to argue that a corporation would only become a truly responsible agent if it were to place its centre of gravitation outside its own narrow limited interests. It would also enable one to argue that a corporation is an entity with a complexity 
of relations in a particular context in relation to which it is possible to apply responsibilities (legal and moral) for its actions. ${ }^{18}$ The difficulties in attributing criminal responsibility to a corporation are not simply related to the inadequacy of the law as it stands, but also importantly to our cultural values, specifically shaped by the standard current notions of individual freedom and responsibility under which human actions are not viewed as being interrelated and interdependent, but as independent and unrelated. As a consequence, and as I have been maintaining all along this article, our Western culture is based on individual values, with a prejudice against collective ones.

However, in spite of much possible agreement with Durkheim, Levinas, nevertheless, differs from and remains very critical of Durkheim. One of his main criticisms is directed against Durkheim's excessive confidence in social institutions/corporations, because from an Levinasian point of view:

(totality), the State, politics, techniques, work at every moment on the point of having their center of gravitation in themselves, and weighing on their own account. (OB: 159)

From the point of view of totality the individuals are not considered on their own, but they are seen simply as elements of the system that overtakes them. Against Durkheim, Levinas does not look for the first element of morality in the elevation of the individual to humanity through his /her participation in the social totality, but in inter-individual relationship. ${ }^{19}$

The stress in the inter-individual relationship as the basis of morality leads Levinas to maintain a critical attitude towards social institutions, which, as such, are indifferent to the fate of individuals. It is precisely because the standard current account of corporations lacks this critical Levinasian attitude that the remit of their responsibility is distorted. Corporations play their own game, with their immanent logic, making sure they rationally manipulate all other parties to advance their own goals. When social relations are reduced to their mere institutional forms, we arrive at an anonymous world, or as Levinas says at an "in-humane neutrality (De L'Existance à L'Existant: 11)." It is this "neutrality" which is at the basis of the view that crimes perpetrated by a corporation are not crimes, but accidents. This is another reason why it is so difficult to attribute criminal responsibility to corporations, and it explains why in the case of the Herald of Free Enterprise, it was not possible to apply the charge of corporate criminality. Within their own limited parameters, corporations cannot be faulted, as long as they are faithful to their own immanent logic. The present difficulty of attributing criminal responsibility to corporations is precisely due to a tacit, if not explicit, acceptance of that logic and framework, a deep-seated reluctance to question it from outside. Ironically, a Durkheimian understanding would simply reinforce such a status quo.

It is not the social totality on its own which Levinas critiques, but the totalization understood as an organisational system in which all forms of social existence are reduced to the limited logic of institutions/corporations. Although individuals do not disappear in the total order, their irreplaceable singularity is diminished, because a totalising system reduces every social relation to a simple form of participation in the social order.

In a corporation all relations are strictly dictated by an internal order and regulated by a standardised behaviour according to the ideology of the corporation or institution, and no deviation could be entertained.

The Levinasian critique of social totality resists the reduction of the social relation only to its objective and institutional expression. The aim of his critique is to alert liberal societies to the fact that totalization is not a deviation of the contingency of the political order but is a permanent threat. Levinas says:

A society respectful of liberties would not simply have as a foundation "liberalism", objective theory of society, which argues that it works better when things are left alone. Such liberalism would make freedom depend upon an objective principle and not from the essential secret of lives. (Éthique et Infini: 73-74)

Levinas contends that no institution or corporation could by its own means limit the extension of its authority. Its boundaries come from the outside, from the parole propre (speech), the Saying as the confirmation of the agent's singularity and at the same time as the expression of my responsibility for the Other and all the others. ${ }^{20}$ The Saying defines the possibility for each agent to speak for him/her- 
self, and in this way be "personally present" in his/ her speech. ${ }^{21}$

\section{Conclusion}

At this point one can say that corporate responsibility is exercised when the singularity of the speech of each agent is not systematically ignored in favour of the established order, but is seriously taken into account. This speech does not only translate the agent's desire to talk in its own name, but defines the social relation, distinct from that of institutions/ corporations. In the words of Wilden this enables:

(the) creativity of labour potential that makes each of us, not an abstract individual - not an economic abstraction exchanging human value for monetary exchange value, not a commodity in the economic machinery worth a specific, competitively defined, quantity of dollars per hour to a part of the system over which we have no control - but a qualitatively differentiated individual, inseparable in the long run from our dependence on complex and undefinable sets of nonexploitative communications and exchanges with our fellow human beings... (1978: 122)

Speech is beyond the domain of the established order and establishes significations. On the one hand, it is the agent's manifestation of his/her power of rupture and on the other hand, it is the opening to unpredictable directions. Responsibility at whatever level - corporate or individual - is unconditional for the Other and all the others. In order to be responsible, as we have seen, is not a question of choice, but a question of a deep liberty, the liberty of taking the burden of the infinite responsibility for the Other - customer, employees, community, public at large, others.

The rupture with the established order instituted by speech allows the existence within public space of another type of social relation, other than the relation reproduced by the logic of any one social order like that of a corporation. Speech disturbs order, but does not propose another stable order in competition or in conformity with a given order. This disobedience of the logic of the social order is a radical protest but without connivance, because this protest does not have the ambition to install a new order; the only "ambition" is to give the first place to the Other.
In the context of corporate legal responsibility, Levinas may be said to be inviting society to make corporations face up to their responsibility for the Other, as well as at the same time to be inviting corporations themselves to accept such responsibility for the Other and, in so doing, to render themselves truly free. In this sense, Levinas's conception of ethics as first philosophy and his aretaic account of ethics constitute a genuine new paradigm.

\section{Acknowledgements}

Sponsored by FCT (Fundação para a Ciência e Tecnologia) and POI2010 (Programa Operacional da Ciência e Inovação).

\section{Notes}

1 Two limitations immediately spring to mind. First, it is true that Levinas himself had no interest in the legal issue of corporate responsibility per se. However, as legal responsibility (especially in the law of homicide) overlaps with moral responsibility, there is nothing in principle objectionable to extending his insight regarding moral responsibility to the area of the law. Second, the scope of his responsibility is only responsibility for the Other human being. As Llewelyn (1991: 114) points out: "(Levinas) is so preoccupied with doing justice to the human being that he fails to do justice to the non-human being, for despite his rare references to our responsibility "for everything"... these go unexplained and stand out as anomalies in writings which say or imply that direct, unmediated responsibility is responsibility to the other human being." But for the purpose of this paper, the latter objection will just be noted, as acknowledging it is not necessarily so damaging.

2 For details of this disaster, see Department of Transport, Report of Court No. 8074 (1987). This report, will be referred to, for short, as the Sheen Report. In brief outline, the salient facts of the case and the findings of the Sheen Report are as follows: The day 6th March of 1987 was a terrible day for the passengers of the Roll on/Roll off ferry Herald of Free Enterprise. The ferry capsized in the approaches to the Belgian port of Zeebrugge en route to Dover in England at 19.05 local time. There was a light easterly breeze and the sea was calm. The ship had a crew of 80 and carried 459 passengers, 81 cars, 3 buses, and 47 trucks. After leaving the harbour, $90 \mathrm{~s}$ later, she capsized ending on her side half-submerged in shallow water. Only an accidental movement 
to starboard in her last moments prevented her from sinking totally in deeper water. After the capsize, a courageous search and rescue operation was raised. At least 150 passengers and 38 members of the crew died from hypothermia, many of them inside the ship or in the frozen water. Many others were injured. The rescuers soon realised that the Herald of Free Enterprise had left the Zeebrugge port with her bow doors open. The design of the Roll on/Roll off ferry boats are essentially pontoons covered by a superstructure, with bow and stern doors which provide the means for vehicles to drive on and off via adjustable ramps at the dock. The speed of a ferry loading and unloading is improved for a Roll on/ Roll off ship, abbreviating the time a ship spends in port. The Sheen Report identified five faults related to safety as the direct cause of the disaster: (a) pressure to leave the berth immediately after the loading; (b) excessive number of passengers; (c) lack of indicator lights "there is no indicator on the bridge as to whether the most important watertight doors are closed or not"; (d) failure to ascertain the ship's draught: "The ship's draught is not read before sailing, and the draught entered into the Official Log Book is completely erroneous. It is not standard practice to inform the Master of his passenger figure before sailing. Full speed is maintained in dense fog"; (e) inadequate capacity of the ballast pumps. The existing pump took $1.30 \mathrm{~min}$ to empty the tanks, which meant that the ferry could not get back on to an even keel until it was well out to sea. A new pump would only have cost $£ 25,000$, but the Company regarded this as prohibitive. The Report found that "(f)rom top to bottom the body corporate was infected with the disease of sloppiness". The board of directors ignored the several recommendations about the safety management of their vessels. Yet, as far as culpability was concerned, the Sheen Report found Captain David Lewry and Mr Leslie Sabel (the Chief Officer) to have been "guilty of serious negligence causative of the casuality. Both these officers have suffered the penalty of having their Certificates suspended (The Sheen Report, 74)." In the light of that, the "Court does not wish to impose on them a heavy financial penalty. (ibid)" As for Townsend Car Ferries Limited, the Report merely concluded that it had no way of marking its "heavy responsibility for the disaster" than paying the sum of \&350,000 towards the payment of the costs of the Court's investigation into the whole tragedy. Justice Sheen significantly remarked: "That seems to me to meet the justice of the case (The Sheen Report, 74-75)."

3 The dominant tradition of Western philosophy views freedom as the most valuable source of morals and politics. Levinas is very critical of this extreme con- fidence in freedom. In TI: 82-84, he devotes an entire section to this matter, "Freedom called into Question". For him, it is not freedom, which is constitutive of the human agent and its identity. For him, morality does not have its source in freedom; instead "morality begins when freedom, instead of being justified by itself, feels itself to be arbitrary and violent (TI: 84)." This is to recognise a principle not only of autonomy, but also heteronomy as the source of all morality, the presence of the Other. The negative sense of heteronomy in Kantian philosophy acquires a positive value in the philosophy of Levinas. However, the autonomy of the human agent is not denied in the philosophy of Levinas but must be seen in relation to heteronomy when I am confronted with the non-me in my self and outside of myself. For Kant, the source of morality is the autonomy of the will, but for Levinas, it is the relation to the irreducible exteriority of the face, as we shall see in a moment. (On Levinas's relation to Kant, see Peperzak (1997: 198-200) and Hayat (1995: 54-56).

4 For now, no further elucidation or comment will be made of this notion, as a more suitable place to elaborate and discuss it is the next section, where a few more Levinasian concepts will also be introduced.

5 In the next section, the related distinction between the Saying and the Said will be discussed.

6 Note that this is the very title of the second major oeuvre of Levinas.

7 See Levinas (1991) in Entre Nous.

8 Otherwise Than Being goes beyond TI (which conceives language as playing a central role in ethical relations because the encounter with the Other always involves speech) in maintaining that the exposure to the Other effected in saying is at the very core of ethical relations; language is neither condition nor source of Saying, but Saying itself. The Other who faces me awakens me to a dimension beyond the universe of beings and their Being. In speaking to somebody I transcend the realm of Being by accepting that my being is meant to be there for the Other: "To say is to approach a neighbour, 'dealing him signifyingness'. This is not exhausted in 'ascriptions of meaning', which are inscribed, as tales, in the said. Saying taken strictly is a 'signifyingness dealt the other', prior to all objectification; it does not consist in giving signs. (OB: 48)."

9 See French (1984) and also, Werhane et al. (2003). 10 See $O B: 159$.

11 This point refers to the Levinasian notion of "the third". In this article I cannot go into further details of the complexities involved. For further discussion, see Bernasconi (1999), Purcell (1996), Faessler (1984).

12 To possible objections to this point, see as defence, Critchley (1992: 232). 
14 On this point, see Critchley (1992).

15 Proximity is the term Levinas uses to refer to the immediacy on confronting the face of the Other. Proximity is felt as immediate contact which demands a response and hence, that it amounts to responsibility, that is to say the ability to respond.

16 Levinas (1972: 95).

17 See, Soares (2003) and Stone (1975).

18 See, Davies (2002) and Quingley (2004).

19 "The social relation is not a relationship initially which goes beyond the individual, with something more than the sum of the individuals and superior to the individual, in the Durkheimian sense (De L'Existance à L'Existant: 161)." [My translation]

20 See TI: 296.

21 See TI: 296.

\section{References}

Bernasconi, R.: 1999, 'The Third Party: Levinas on the Intersection of the Ethical and the Political', Journal of the British Society for Phenomenology 30(1), 76-87.

Critchley, S.: 1992, The Ethics of Deconstruction: Derrida and Levinas (Edinburgh University Press, Edinburgh).

Davies, P.: 2002, Introduction to Company Law (Oxford University Press, Oxford).

Faessler, M.: 1984, 'L'Intrigue du Tout_Autre: Dieu dans la Pensée d'Emmanuel Levinas', Les Chaiers de la nuit surveilée (Verdier, Paris) pp. 119-145.

French, P.: 1984, Collective and Corporate Responsibility (Columbia University Press, New York).

Hayat, P.: 1995, Emmanuel Levinas: Éthique et Société (Editions Kimé, Paris).

Kearney, R.: 1994, 'Dialogue with Emmanuel Levinas', Dialogue with Contemprary Continental Thinkers (Manchester University Press, Manchester).

Levinas, E.: 1967, Totalité et Infini: Essai sur Léxteriorité (Biblio Essais, Paris).
Levinas, E.: 1991, Entre-Nous: Essais sur le penser-à-l'autre (Bernard Grasset, Paris).

Levinas, E.: 1982, Éthique et Infini: Dialogues avec Philippe Nemo (Fayard/Culture, France, Paris).

Levinas, E.: 1990, De L'Existance à L'Existant (Vrin, Paris).

Levinas, E., 1998, 'Otherwise than Being: Or Beyond Essence', trans. By Alphonso Lingis, Pennsylvania, Duquesne University Press.

Levinas, E.: 1972, L'Humanisme de L'Autre Homme (Biblio Essais, Paris).

Llewelyn, J.: 1991, The Middle Voice of Ecological Conscience: A Chiasmic Reading of Responsibility in the Neighbourhood of Levinas, Heidegger and Others (Macmillan Academic and Professional Ltd, London).

Peperzak, A.: 1997, Beyond-The Philosophy of Emmanuel Levinas (Northwestern University Press, Evanston, Illinois).

Pilger, J.: 2001, 'Spoils of a Massacre', The Guardian, Saturday 14, July, 18-29.

Purcell, M.: 1996, 'The Ethical Significance of Illeity (Emmanuel Levinas)', Heytrop Journal 37(2), 125-38.

Quingley, W.: 2004, 'Catholic Social Thought and the Amorality of Large Corporations: Time to Abolish Personhood', Loyola Journal of Public Interest Law, 5 109, 46-70.

Soares, C.: 2003, 'Corporate Versus Individual Moral Responsibility', Journal of Business Ethics 46, 143-150.

Stone, D. C.: 1975, Where the Law Ends: The Social Control of Corporate Behaviour (Harper Torchbooks, New York).

Werhane, P. et al.: 2003, 'Corporate Responsibility', in H. L. Follete (ed.), The Oxford Handbook of Practical Ethics (Oxford University Press), pp. 514-536.

CEGE/Faculty of Economics and Management, Catholic University of Portugal-Porto,

Rua Diogo Botelho, 1327, Porto, 4169-005, Portugal E-mail: csoares@porto.ucp.pt 